\title{
The USA Federal Debt-to-GDP Ratio and The Unified Budget Act's Lack of Generally Accepted Accounting Principles
}

https://doi.org/10.21272/sec.5(2).49-57.2021.

Paul F. Gentle, ORCID: https://orcid.org/0000-0002-0317-0166

$\mathrm{PhD}$, Economics Researcher, Auburn University, AL, USA

\begin{abstract}
Here in the beginning of 2021, two of the truly relevant federal public finance issues are presented in this article. One is the Debt-to GDP Ratio. The second topic is the true nature of deficits, surpluses and future liabilities treated in budgets constructed via the Unified Budget Act. Two graphs on these issues are included. This article shows that the present Debt-to-GDP ratio is relatively high, as if the nation similar to when the United States was in a period of a major war. This graph is shown in this article's Figure 1. There has been evidence in the macroeconomic literature that indicates a high Debt-to-GDP ratio can possibly result in some degree of slowed economic growth. Though the literature is varied on that point. The reason for the possible crowding out effect has to do with the competition for loanable funds. There is competition from both the public and private demanders of those loanable funds. Furthermore, there is the reality that all federal trust fund balances of the United States must be used to hold U.S. Treasury bonds. For figure 2, two categories on U.S trust funds are shown. One category is the combined total of Social Security. Medicare, Disability and related funds. This is shown in a red line. All the other federal trust funds are indicated in a blue line. There is a graph that shows these two lines. The graph is of the percentage share between the two categories. As a result, the red and blue lines are inverse functions of each other. Over the eighty-year period (1940-2020), there has been variation if both the red and blue lines. The goal of this articles is for leaders and government analysts to be more aware of the issues of the USA Federal Debt to GDP Ratio and the Unified Budget Act's lack of Generally Accepted Accounting Principles.
\end{abstract}

Keywords: United States Debt-to-GDP Ratio, Unified Budget Act, Social Security.

JEL Classification: E0, H6, H2.

Cite as: Gentle, P.F. (2021). The USA Federal Debt-to-GDP Ratio and The Unified Budget Act's Lack of Generally Accepted Accounting Principles. SocioEconomic Challenges, 5(2), 49-57. https://doi.org/10.21272/sec.5(2).49-57.2021.

$\begin{array}{lll}\text { Received: } 15.03 .2021 & \text { Accepted: 14.06.2021 } & \text { Published: 25.06.2021 }\end{array}$

Copyright: (C) 2021 by the author. Licensee Sumy State University, Ukraine. This article is an open access article distributed under the terms and conditions of the Creative Commons Attribution (CC BY) license (https://creativecommons.org/licenses/by/4.0/).

\section{Introduction}

The United States budget takes a little time to understand. Policy makers, public administrators, accountants, economists, and others have to be mindful of course of the two major phenomena of the Debt-to-GDP ratio and the Unified Budget Act's lack of adherence to generally accepted financial principles. Other topics are important as well. It is hoped that these elected officials can effectively deal with all the major budgetary phenomena.

The concern with the Debt-to-GDP ratio has to do with the idea that if the ratio is too high, it will slow economic growth. Many business firms, consumers and the government compete for loanable funds. By law, any federal debt has to be supported by the holding of U.S. Treasuries. This article examines the Debt-to-GDP ratio. Also, there is discussion about how future liabilities are not considered in determining the reported deficits and debt in budget documents that are governed by the Unified Budget Act of the USA. 
Special attention is given to Social Security and Medicare trust funds and related trust funds. Two graphs help to give an overview of the current situation concerning both the Debt-to-GDP ratio, as well as some Unified Budget Act realities. Discussion regarding policy alternatives is provided in a beginning way and the reader is invited to take these ideas further. Finally, there is a summary and conclusion section.

\section{The Debt-to-GDP Ratio: Literature Review and Application}

This leads us to the first topic of this article. In contemplating a national debt, one has to state why debt is important in the first place. In ascertaining, the possible negative effect is by examining the national Debt-toGDP ratio. If the ratio becomes too high, there may be an effect on future public and private borrowing ability (Mankiw, 2006; 2012; Gordon, 2009; Wallner, 2011; Gentle et al., 2013). In Gentle et al (2013), the impact of the Unified Budget Act was explained. With that Act, all revenues, and all expenditures were shown. Although with this Act, future liabilities are not specified in a Unified Budget. In Gentle (2020), it was noted that in the first place, the COVID-19 virus caused there to be less revenue coming in for taxes in general and for Medicare and Social Security with Disability specifically, as less people were working. Simultaneously, more benefits from those programs may have been paid out, than expected due to the COVID-19 virus (Gentle, 2020). So, under the Unified Budget Act, the federal deficit increases in the presence of the COVID-19 epidemic. After this article examines the federal debt-to-GDP ratio, more is said about the Unified Budget Act, itself.

The Gross Domestic Product (GDP) of a nation consists of all the goods and services produced in the economy of that country. By comparing GDP to the federal debt, the result is an image of the nation's economy and the ability of the federal government's "fiscal health and its ability to service the debt" (Congressional Budget Office, 2020). The Congressional Budget Office typically reports both on the amount of debt held by the public and on that debt as a percentage of GDP. The Debt-to-GDP ratio provides a view of debt in relation to the size of the economy and is a useful measure for comparing amounts of debt in different years. There is a key caveat to keep in mind. For the Debt-to-GDP ratio, only federal debt held by the public is included. This includes a very sizeable amount of U.S. Treasury securities that are held by balances in the federal trust funds (Congressional Budget Office, 2020). Moreover, Cebula and Boylan (2019) note that deficits and debt by the federal government may be a factor in having an impact on real interest rates.

\section{Graphical Analysis}

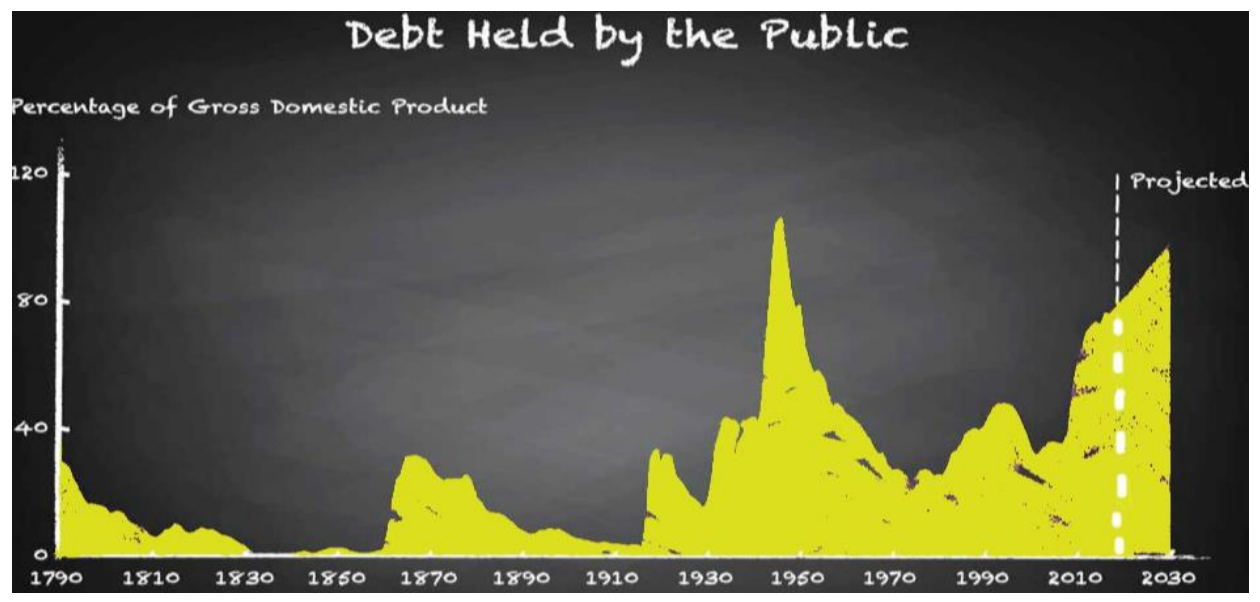

Figure 1. Adapted from Congressional Budget Office (CBO) (March 2020). This figure shows a specific the federal U.S. Debt-to-GDP ratio. The debt figures are based on federal debt held by the public

Source: CBO (March 2020).

In the above graph the time length is from 1790 through March 2020. A key point is that the figures are only until March 2020. That means that the worsening economy due to COVID-19 may not be accurately reflected fully here. The dotted line indicates the Debt-to-GDP ratio in March,2020. Beyond that the graph is a projection of future values. In the graph above, one can note the large Debt-to-GDP ratio during World War II. Of course, 
loanable funds used to help state and local governments public debt also means some less loanable funds available for the private sector (Congressional Budget Office, 2020).

The term "debt held by the public" is all debt financial instruments that the federal government are held outside of the federal government. This includes debt held by individuals, businesses, banks, insurance companies, state and local governments, investments, foreign governments, foreign businesses and individuals, and the U.S. Federal Reserve Bank. So, the U.S. Treasuries held by federal trust funds are not counted as debt held by public. Furthermore, using debt held by the public is what is commonly used in Debt-to-GDP ratio analysis. The measurement ratio of publicly held debt to GDP is a better measure of a country's fiscal situation than just the nominal debt figure because it shows the burden of debt relative to the country's total economic output and therefore its ability to finance or repay it. This measure allows for an apples-to-apples comparison of one country's fiscal situation over time in a meaningful way. A large nominal dollar debt is less of a problem if a country has a large economy measured as a large GDP. The Debt-to-GDP ratio is now at its highest level since World War II (Congressional Budget Office, 2020).

It is important to know that various transactions that occur in any year between the trust funds and the Treasury are intragovernmental. Examples of these trust funds are Social Security Trust and Medicare and any other federal trust funds. These transactions "have no net effect either on federal borrowing from the public or on the total budget" ( Congressional Budget Office, 2020). The Treasury retains the annual surplus cash flows from a federal trust fund program's activity, and the trust fund is credited with a corresponding amount of nonmarketable Treasury securities. Then the Treasury uses the cash to finance the government is other activities (Congressional Budget Office, 2020).

\section{Unified Budget Act : Literature Review and Application}

The possible impact of the debt-to-GDP ratio is further complicated by the Unified Budget Act (UBA). During the fiscal years of 1935 through 1968, the Social Security trust funds were shown as off budget, since they were for a specific function (Erdevig, 1990; Social Security, 2006). After fiscal year 1969, the federal budget was based on a cash basis accounting system, as opposed to the accrual system. The Unified Budget Act caused this change. (Erdevig, 1990; Webb, 1991; U.S. Treasury, 2002; Social Security, 2006; Averkamp, 2008). So, in the USA, the Senate, House of Representatives, and President are using a federal budget, based on the cash system of accounting. Amazingly the Highway Trust Fund, the Medicare Trust Fund, and all other federal trust funds are no longer treated as separate items, with the Unified Budget Act, from the unified federal budget. Importantly, any balances in any federal trust can only be used to hold United States Treasury securities (Gentle et al., 2013).

In 2017, the rating for long-term U.S. Treasury Securities remined at AA+ by Standard and Poor's, a credit rating firm. The AA + stayed, instead of the top one of AAA is because this brings attention to the fact that both Congress and the U.S. President needed to work together to slow the growth of annual deficits, which add to the federal debt. Interestingly, two other bond rating firms, Moody's Investors and Fitch maintained the bond rating of AAA. It must be remembered that none of these ratings are permanent. As time continues, firms that give bonds ratings will continue to analyze those who issues securities, including the USA government (Swann et al., 2011; Gentle et al., 2013; Reutter's Staff, 2017).

In early August of 2020, then President Trump signed an executive order which permitted companies to stop withholding payroll taxes from their employee paychecks, a scheme to increase take-home pay. Amazingly, Trump promised that he would cancel the tax altogether if he were to be reelected in November. Such a move has little support from either party on Capitol Hill. Therefore, it is unlikely to advance. Federal payroll taxes fund Social Security. Not surprisingly Trump's proposal to eliminate payroll taxes would deplete the Social Security retirement trust fund by 2023 and the disability insurance fund by the middle of 2021, according to people at 
Social Security Administration (Goss, 2020). Trump lost the 2020 presidential race and so his proposal to cancel the tax altogether, will not be considered. ${ }^{1}$

Most importantly, President Biden has taken a different route concerning strengthening Social Security. During the 2020 campaign, President Biden ran on important ideas regarding increasing the solvency of the Social Security programs. Furthermore, Biden wishes to increase the benefits. How Congress and the president will approach these challenges will be important. Advocates of Social Security and other experts point out that improvements have to be made as soon as possible. The situation demands immediate attention on behalf of President Biden and Congress ( Konish, 2020). As Altig et al (1996) explain changes to the Social Security system attract voter attention and so good political leaders are careful about any decisions.

All U.S. Trust Funds surpluses, by law, must be used to hold U.S. Treasury securities (Gentle et al., 2013). In contemplating the future, one can see that in order for the USA to continue entitled programs, such as Medicare and Social Security, there are some option to choose from. These include increasing the retirement age, increasing relevant taxes, decreasing benefits or some combination thereof (Rivlin et al., 1990). Amendments to the 1983 Social Security Act have been used to increase funding to the trust funds that provide payments to beneficiaries for Social Security, including disability , as well to Medicare (Erdevig, 1990; Rivlin et al., 1990; Carlson, 1991; Anderson, 2005) . Although what Trump did in August 2020, concerning payments deducted from paychecks, caused some decrease in revenues to important federal entitlement, partially funded by payroll deductions. (As a non-partisan economist, the author of this article has only served in government positions, legally mandated as non-partisan).

In Gentle et al. (2013), China held the greatest amount of debt and Japan was second. The amounts are constantly updated. The two foreign countries that hold the most U.S. Treasury debt now are Japan, first and China is second. The numbers for both 2013 and 2020 in regard to China are actually just for Mainland China (U.S. Treasury International Capital Systems, 2013, 2020). Foreign investors are important holders of U.S. Treasury debt and so are domestic holders including the U.S. government itself ( Jackson, 2008). This includes the various U.S. government trust funds and the Federal Reserve). One way the U.S. federal government deals with what may viewed as too much, is for the Treasury to sell securities to the Federal Reserve. This tactic is known as monetizing the debt and if it is done too much; this can lead to varying degrees of inflation (Bonner, 2009; Powell, 2009; Labonte, 2012). The total federal debt is an estimated \$ 23.90 trillion in 2020 (OMB, 2020).

Due to the UBA not following Generally Accepted Accounting Principles (GAAP), the resulting budget does not show accrued liabilities. Therefore, the UBA has resulted in cash budgets (U.S. Treasury, 2002). Along with cash

\footnotetext{
${ }^{1}$ Most U.S. Senators and U.S. Congressional Representatives found Trump to be largely responsible for encouraging a riot by thousands of his supporters, in an act of domestic terrorism which forcefully invaded the capitol. This was to stop the Constitutionally mandated, lawful counting of electors on January 6, 2021. For impeachment in the House and conviction in the Senate, there were both Republican and Democrat support. Although most Republican House members and Senators did not support impeachment or conviction. To the disappointment of many Americans, Trump was not convicted, due to a lack of the required two-thirds senators voting for that. Some people have spoken of court proceedings against Trump, for both the January 6 incident and other matters that Trump may be at least partially responsible for (Hickey et al., 2021; Linton et al., 2021; Poniewozik, 2021). Interestingly in American history, no president has ever been convicted by the Senate. The unanimous opinion of every single judicial court has been that Biden and Harris won the 2020 general election for president and vice-president, respectively, by both popular vote and electoral count. In contrast to Trump, all other candidates who lost a presidential election in American history never sought to overturn the results by inciting a riot to stop the official counting of electoral votes in the U.S. capitol. In American history one can note some presidential elections that had disputed and/or close results. However, only Trump inflamed domestic terrorists, who broke into the capitol and caused multiple deaths (Poniewozik, 2021; Kupchan et al., 2021). The author is so glad to enjoy studying economics and government in an objective way, without trusting sales pitches from politicians, in general. The author thinks some policies may be better than others but any analytical work the author does or has done is objective and provided for all politicians on all sides of an issue. It is up to the political people to debate decisions, not the author or his colleagues. All the author's posts in government as an analyst were by law non-partisan, which the author preferred. He worked as a full-time economist at the local and state level, for a university research council and as a post-doc fellow working on federal research reports. The author also did some non-partisan research work with colleagues for the UN. Even in a non-partisan way, one can admire then Vice-President Pence for doing his Constitutional duty of having the electoral votes counted on January 6 and continuing that activity until that legal requirement was met.
} 
budget accounting, there is no regard for indicating expenditures in the future (Cunningham, 1989; U.S. Treasury, 2002; Averkamp, 2002). Yet as Garner (1989) points out, the Unified Budget Act deficits or surpluses are the most quoted, when people speak about the federal budget. Accumulated deficits and surpluses determine the federal debt. Though the U.S Treasury also uses an accrual budget, different than the budget that is used by the Office of Management and Budget and the Congressional Budget office (U.S. Treasury, 2002, Lewis, 2006; Congressional Budget Office, 2020; Office of Management and Budget, 2020). Wallner (2011) suggests that when the Congress is adopting the budget, future liabilities should be taken in consideration, not just the next fiscal year.

With more and more Americans retiring from the baby boomer generations, the Medicare and Social Security administration will have to sell U.S. Treasury securities (Cunningham, 1989; Erdevig, 1990). Those Americans born between 1946 and 1964, inclusive, constitute the baby boomer generation. Many foreign assets are not as reliable as U.S. Treasury securities. There is also the lack of certainty of the World to be willing to hold as many U.S. Treasury securities as we go into future decades in the middle of this century (Cunningham, 1989). Former Fed Chair Alan Greenspan points out that investing any balance of Social Security in the stock market would be problematic. If that were done for any the chance getting a higher rate of return on investment, so as to possibly have higher return on investment would then necessitate other sources of funds to hold an equivalent amount of Treasuries (Forsyth, 1996; McCurdy and Shoven, 1999). Furthermore, the National Bureau of Economic Research found no certainty in improving the finances of the Social Security Trust fund through an investment in common stocks instead of Treasury bonds (McCurdy and Shoven, 1999).

In the coming decades, the federal government will simultaneously have to taking care of the federal debt and repay the money borrowed from trust funds associated with Social Security. The federal government will also be faced with maintaining adequate funding for Medicare and other necessary programs. When the federal government issues more Treasury bonds, this causes there to be less loanable funds for the private sector. Foreign holders of Treasury bonds can be helpful as a source of financing federal government operations and other expenses. Yet those foreign funds may then be less available to private investment, to some degree (Erdevig,1990; Regalia, 1995).

A common acronym used to denote the Old Age, Survivors, and Disability Insurance is OASDI. Payroll tax receipts, interest income from U.S. Treasury securities held by OASDI and any other income. Any balances in Medicare or other federal trust funds must be used to held U.S. Treasury securities. All expenses for OASDI and Medicare are met by those trust funds mentioned in this paragraph (Erdevig, 1990). In addition, positive balances in those trust funds and all other federal trust funds such as the Airway and Federal Civilian Retirement trust funds are used to hold balances (Jackson, 2006; Qrszag, 2007; Office of Management and Budget, 2013).

\section{Graphical analysis of the UBA Impact}

At the end of Fiscal Year 2020, the various trust funds of the USA Federal Government held \$23.90 Trillion dollars of USA Treasury securities. Figure 2 includes all the trust fund balances. However, this figure does not include holdings by the U.S. Federal Reserve System (Congressional Budget Office, 2020). The Federal Reserve (the Fed) buys and sells U.S. Treasury bonds as part of its monetary policy. The buying and selling securities by the Fed are only part of how the Federal Reserve implemented its monetary policy. For more on the subject about how all the ways that the Federal Reserve implements monetary policy, one can refer to Mishkin (2018). This graph is an updated graph from Gentle et al., 2013. To construct this type of graph, several annual series of numbers had to be collected from historical tables for the United States federal budget, which are found in Office of Management and Budget (2020). This is the same, exact step-by-step procedure that was used in Gentle et al. (2013). Figure 2 uses a percentage comparison. One can see from changes in the lines, that the percentage share of Social Security, Medicare, Disability and related programs holdings of U.S. Treasury bonds versus bond holdings of all other related trust funds has changed over time. The Congressional Budget Office (2020) states that "the value of intragovernmental Treasury securities is not, however, a meaningful measure of the government's long-term obligations for those programs." This absence of indicated future liabilities has been discussed clearly in section III of this article. 


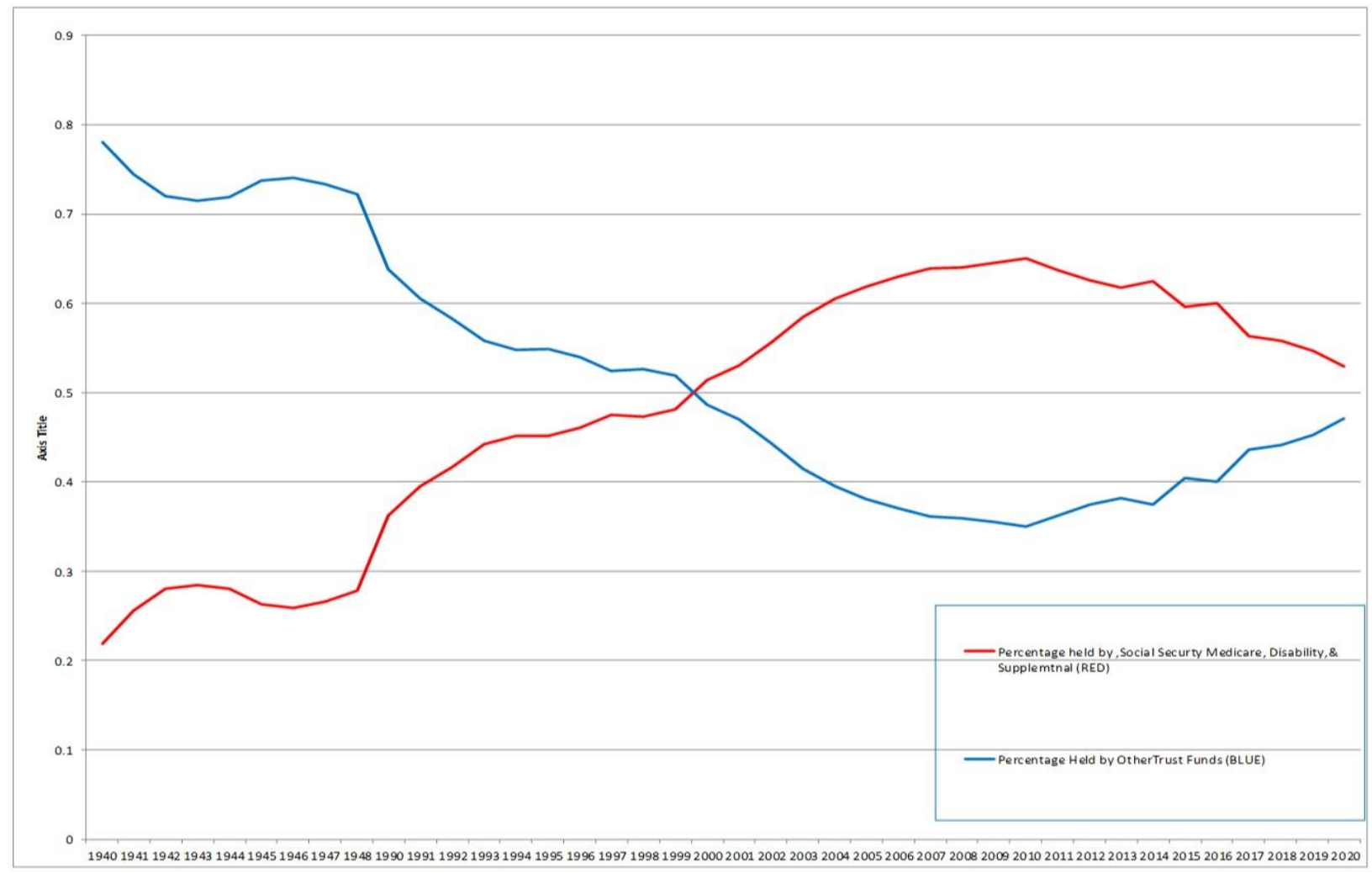

Figure 2. This is a comparison between U.S. Treasury securities held by the trust funds of Social Security, Medicare, and Disability and related and those U.S. Treasury securities held by other trust funds. This graph is for Fiscal Year 1940 through Fiscal Year 2020

Source: OMB (2020).

In order to gather the actual amounts of holdings of U.S. Treasuries by dollar amounts, the author of this article consulted the historical tables of the U.S. budget. The historical tables of the Office of Management and Budget (2020) provided the data. To arrive at the percentage number used in the red colored line, one first sums of these programs, for each fiscal year from these historical tables: "Social Security," "Medicare," "Disability Income," "Hospital," and "Supplemental." The Hospital and Supplemental funds are related to the broad category of Social Security, Medicare and Disability. Therefore, the dollar amounts for Hospital and Supplemental are included in the total dollar amounts for Social Security, Medicare and Disability. However, to arrive at the percentage number used in the blue colored line, one first examines the total amount of Treasury bonds held by all U.S. federal trust funds and subtracting out "Social Security," "Disability Income," "Hospital," and "Supplemental." That remaining sum allows us to see how much the other trust funds holds in U.S. Treasury bonds. Clearly, the relative holding of U.S. Treasury securities amongst federal trust funds has changed sometimes in the period from Fiscal Year 1940 through Fiscal Year 2020. The years Fiscal Years 1999 and Fiscal Years 2000 are the general area, when the red line is higher than the blue line. The red line indicates the share of U.S. Treasury bonds held by Social Security, Disability and Medicare. Hospital and Supplemental are just an additional part of Medicare. The blue line denotes the varying percentages of the share held by all government trust funds. Furthermore, compared to the percentage held of all the other federal trust funds varied. The two lines in the graph are inverse functions of each other. Reasons for the fluctuations of these lines through time, has to do with the revenues and 
expenditures for each category of trust funds. Explaining what happened in each of the eighty years (1940-2020) is beyond the scope of this article ${ }^{2}$.

\section{Summary and Conclusion}

In this article, two major phenomena are examined. One is how the Debt-to-GDP ratio has changed since the beginning years of the United States until March 2020, with some projection for years in the future. The other phenomenon is the Unified Budget Act. Included in this section is the realty that federal trust funds are used to hold U.S. Treasury Securities. Here in 2021, policy makers, public administrators, accountants, economists, and others must be cognizant of the course of these two major phenomena. There are certainly other major factors but these two cannot be ignored. The U.S. Debt-to-GDP ratio has fluctuated over the years and is high at the present time, somewhat similar to the time of being in a major war. The Unified Budget Act has included varying amounts of federal trust funds over the time from Fiscal Year 1940 through Fiscal Year 2020.

Funding: self-funded.

Author contribution: conceptualization: Paul F. Gentle; data curation: Paul F. Gentle; formal analysis: Paul F. Gentle; funding acquisition: Paul F. Gentle; investigation: Paul F. Gentle; methodology: Paul F. Gentle; project administration: Paul F. Gentle; resources: Paul F. Gentle; software: Paul F. Gentle; supervision: Paul F. Gentle; validation: Paul F. Gentle; visualization: Paul F. Gentle; writing - original draft: Paul F. Gentle; writing - review \& editing: Paul F. Gentle.

\section{References}

1. Altig, David and Gokhale, Jagadeesh (1997). A Simple Proposal for Privatizing Social Security. Economic Commentary, Federal Reserve Bank of Cleveland, May 1, pp. 1-4. Available at: [Google Scholar], [Link].

2. Anderson, Richard G. (2005). Tips for Social Security? National Economic Trends Federal Reserve Bank of Saint Louis, April. Available at: [Google Scholar], [Link].

3. Averkamp, Harold B. (2008). CPA, Accounting.coach.com. Available at: [Link].

4. Bipartisan Commission (1995). Bipartisan commission on entitlement and tax reform: final report to the president Washington, D.C.: Superintendent of documents. Available at: [Link].

5. Bonner, Bill (2009). The Future Will Come: Fleet Street Invest. Available at: [Link].

6. Carlson, Keith M. (1991). The Future of Social Security: An Update. Review, Federal Reserve Bank of St. Louis, 73 (1), 33-49. Available at: [Google Scholar], [Link].

7. Cebula, Richard J. and Robert Boylan, (2019). An Empirical Analysis for the U.S. of the Impact of Federal Budget Deficits and the Average Effective Personal Income Tax Rate of the Ex Post Real Interest Rate Yield on Ten Year Treasuries. PSL Quarterly Review, pp. 41-52. Available at: [Link].

8. Committee for a Responsible Federal Budget (2017). Q\&A: Gross Debt versus Debt Held by the Public. Available at: [Link].

9. Congressional Budget Office (CBO) (2020). Federal Debt: A Primer. Available at: [Link]. https://www.cbo.gov/publication/56165.

10. Cunningham, Thomas J. (1989). The Federal Budget Deficit and the Social Security Surplus. Economic Review (Federal Reserve Bank of Atlanta), 74 (2), pp. 2-13. Available at: [Link].

11. Erdevig, Eleanor (1990). The need for social security reserves and their effect on the budget. Economic Perspectives (Federal Reserve Bank of Chicago), 14 (6), November/December, pp. 16-23. Available at: [Google Scholar], [Link].

12. Forsyth, Randall W. (1996). Putting Social Security "Surpluses" into Stocks Ranks as One of the World's Nuttiest Ideas. Barron's, 76 (10), March 4. Available at: [Link].

13. Gamer, C. Alan (1989). The Social Security Surplus: A Solution to the Federal Budget Deficit? Economic Review (Federal Reserve Bank of Kansas City) 74, May, pp. 25-39. Available at: [Google Scholar], [Link].

\footnotetext{
${ }^{2}$ The author thanks Brooks Lide was helpful in labeling the horizontal axis of Figure 2 in this article.
} 
14. Gentle, Paul F., Terri Jett, Jose' Falck-Zepeda, Tao Chin, and Hong Ming, (2013). Issues to Consider: The Federal Unified Budget Act and the Lack of following Generally Accepted Accounting Principles and Implications for Future Liabilities. Banks And Banking Systems, 9(4), 8-12. Available at: [Google Scholar], [Link].

15. Gentle, Paul F. (2020). The Economic Impact of the COVID-19 Virus and Considerations of the United States Unified Budget Act. Strategies in Accounting and Management, 1(5), 1-2. Available at: [Link].

16. Gordon, Robert J. (2009). Macroeconomics, 11th edition, New York: Pearson-Addison-Wesley. Available at: [Link].

17. Goss, Stephen C. (2020). Session 1d: Updates on Proposed Changes and (Current) Financial Status of Social Security. Available at: [Link].

18. Hickey, Christopher, Jane Boschma and Sean O'Key, (2021). How each member of the Hose voted on Trump's Second impeachment. CNN Politics, January 13. Available at: [Link].

19. Jackson, James K. (2008). Foreign Ownership of U.S. Financial Assets: Implications of a Withdrawal - RL 34314. CRS Report for Congress, January 14, pp. 1-15. Available at: [Link].

20. Konish, Lorie (2020). Biden's platform calls for big changes to Social Security. Here's what could be on the table. CNBC, November 19. Available at: [Link].

21. Labonte, Marc (2012). Is the U.S. Current Deficit Sustainable- CRS Report R40770, pp. 1-16. Available at: [Link].

22. Lewis, Becky (2006). Treasury Department Reports Deficit on an Accrual Basis. OMB Watch. Available at: [Link].

23. Linton, Caroline, Grace Segers, Kathryn Watson and Melissa Quinn, (2021). Senate votes to acquit Trump in his second impracment trial. CBS News, February 14. Available at: [Link].

24. Mankiw, N. Gregory. (2006). Intermediate Macroeconomics, New York: Worth Publishers. Available at: [Google Scholar], [Link].

25. Mankiw, N. Gregory. (2013). A Sustainable Budget Should Endure a Storm. New York Times, March 30. Available at: [Link].

26. McCurdy, Thomas E. and James B. Shoven (1999). Asset Allocation and Risk Allocation: Can Social Security Improve its Future Solvency Problem by Investing in Private Securities? National Bureau of Economic Research Working Paper 7015. Available at: [Google Scholar], [Link].

27. Mishkin, Frederic (2018). The Economics of Money, Banking and Financial Markets, $12^{\text {th }}$ ed. Boston: Pearson. Available at: [Link].

28. Office of Management and Budget (OMB) (2013). Executive Office of the President (2013). Historical Tables for the Budget of the United States Government, Fiscal Year 2013, Washington, D.C.: U.S. Government Printing Office. Available at: [Link].

29. Office of Management and Budget (OMB (2020)). Executive Office of the President (2020). Historical Tables for the Budget of the United States Government, Fiscal Year 2020, Washington, D.C.: U.S. Government Printing Office. Available at: [Link].

30. Poniewozik, James, (2021). Critics' Notebook: Donald Trump's Last Picture, Show. New York Times, January 6. Available at: [Link].

31. Reuters Staff (2017). S\&P sees U.S. keeping AA+ rating if it avoids default. August 9. Available at: [Link].

32. Rivlin, Alice, Ralph Bryant, Charles Schultze, Joseph Whaite and Aaron Wildavsky (1990). Four Reasons Not to Cut Social Security Taxes. The Brookings Review, 8, pp. 3-8. Available at: [Link].

33. Social Security (2006). Research Note Number 20: The Social Security Trust Funds and the Federal Budget. Agency History Research Notes \& Special Studies by the Historians Office, September 13. Available at: [Link].

34. Swann, Nikola G. John Chambers, and David T. Beers (2011). United States of America Long-Term Rating Lowered to "AA+" Due to Political Risks, Rising Debt Burden, Outlook Negative. Standard and Poor's Benchmarks, Research, Data and Analytics, August 5. Available at: [Google Scholar], [Link].

35. U.S. Department of the Treasury (2002). U.S. Government Releases FY2001 Financial Report Importance of Financial Reporting Highlighted. U.S. Department of the Treasury Press Room, P0-2049, March 29. Available at: [Link]. 
36. U.S. Treasury International Capital Systems (2013). Major Foreign Holders of Treasury Securities. Available at: [Link], web page on September 9, 2013

37. U.S. Treasury International Capital Systems (2020). Major Foreign Holders of Treasury Securities. Available at: [Link], web page on November 10, 2020.

38. Wallner, James I. (2019). The Unified Budget Accounting in the United States Congress: The Persistence of Government Deficits and Debt, 1967-2010. Forum, 8(4), 1-14. Available at: [Google Scholar], [Link].

39. Webb, Roy (1991). The Stealth Budget: Unfunded Liabilities of the Federal Government. Economic Review (Federal Reserve Bank of Richmond), 77 (2), May/June. Available at: [Google Scholar], [Link]. 